\title{
PEDAGOGICAL SUPPORT OF GIFTED CHILDREN AND YOUTH IN THE OUT-OF-SCHOOL EDUCATION INSTITUTIONS IN THE USA, CANADA AND UKRAINE
}

\section{Maryna Boichenko}

\section{INTRODUCTION}

Rapid political and socio-economic changes require new generation of citizens-innovators, able to respond adequately to the challenges of society, solve creatively non-standard problems. It is indisputable that development of the intellectual and creative potential of the citizens is a prerequisite of high competitiveness of the state, the key to its economic well-being. In this context actualizes the issue of providing high quality pedagogical support for gifted children and youth as a future national elite.

Despite the fact, that there are different models of pedagogical support provision in different countries, in a generalized form they can be divided into two large groups, based on such criteria, as environment and forms of pedagogical support. Consequently, pedagogical support for gifted children and youth is provided in schools and out-of-school education institutions, while the most common forms are acceleration, enrichment, differentiation and ability grouping.

In the framework of our study we'll focus on out-of-school education institutions as an important provider of pedagogical support for gifted children and youth in the USA, Canada and Ukraine. In the course of the study we'll make an attempt to answer the following questions: How children and youth with different types of giftedness are identified in the USA, Canada and Ukraine? What forms of pedagogical support are available in the out-of-school environments of the specified countries? Can positive conceptual ideas of US and Canadian experience be implemented in practice of domestic out-of-school education institutions?

The integrity of consideration of the phenomenon under study is ensured by the comprehensive application of a set of methodological approaches, to which we refer systems-synergetic, personality-centered, cultural and comparative ${ }^{1}$.

${ }^{1}$ Boichenko, M., Sbruieva, A. (2019). Methodological model of comparative research in gifted education in the USA, Canada and the UK. Pedagogical sciences: theory, history, innovative technologies, 4 (88), 151-163. DOI 10.24139/2312-5993/2019.04/151-163. 
Systems-synergetic approach provides a structural-logical analysis of gifted education development in the USA, Canada and Ukraine and makes it possible to consider it as a socio-cultural phenomenon, as a multifunctional, nonlinear, complex, adaptive, dynamic system of interrelated and interacting elements, capable of self-organization and self-development. Its strategic goal is achieved through creating conditions for pedagogical support of gifted children and youth according to their interests and needs.

Personality-centered approach allows us to focus on the personality of a gifted child. The relevance of applying this approach is determined by the need to form gifted children and youth with bright individual personality traits that will enable them not only to save their identity in a rapidly changing society, but also to compete in the labor market.

Cultural approach focuses on understanding educational traditions in the context of other cultures, values and mentality. Understanding culture, together with Canadian scientist W. Masemann ${ }^{2}$, as a phenomenon related to all aspects of life (people's ideas, their relationships with each other, their families, social institutions, language they communicate, physical environment and technology used in society), encompassing mental, social, linguistic and physical forms, allows us to highlight peculiarities of pedagogical support of gifted children and youth in out-of-school education institutions in the USA, Canada and Ukraine.

Comparative approach is applied with the aim of finding out similarities and differences in the phenomenon of gifted education in the studied countries, cause and effect links for explaining dynamics of the national systems of gifted education development, specific forms of pedagogical support of gifted children and youth in each country.

\section{Identification of children and youth with different types of giftedness in the USA, Canada and Ukraine}

The first stage of pedagogical support provision is identification of gifted children and youth. There are different approaches to identification of gifted students in the USA, Canada and Ukraine. In the USA and Canada providers of pedagogical support focus on personal characteristics of gifted children and youth, primarily, abilities in different spheres, which are identified with the help of interviews (with a gifted child, his/her parents, teachers, psychologists and others), tests, questionnaires, observations, analyses of students' portfolios/creative products and so on. In Ukraine, according to the

2 Masemann, V. L. (2013). Culture and education. In R. F. Arnove, C. A. Torres, F. Stephen (Eds.), Comparative education: the dialectic of the global and the local, (pp. 113-131). Lanham: Rowman \& Littlefield. 
Law "On Basic Foundations of State Support of Gifted Children and Youth in Ukraine" the child/young person is considered gifted if he/she is a winner of different competitions, contests, Olympiads (and has corresponding certificates) or has high learning achievements ${ }^{3}$.

Unfortunately, not all children have a possibility even to participate in the above-mentioned events, and they can't bring the corresponding certificates. In this case their giftedness will go unnoticed and they will never get support. In this regard we consider it important for teachers, parents and other stakeholders of gifted services provision to know the main characteristics of gifted children and youth according to the types of giftedness.

In our study ${ }^{4}$ we outline the following types of giftedness: intellectual; specific academic (mathematical, linguistic, etc.); technical; musical and performance; artistic; sports; creativity; leadership. Below we will consider these types in more detail.

Intellectual giftedness, according to the definition provided on the website of the National Society for the Gifted and Talented (USA), implies presence of intellectual abilities far above average, in particular: abstract thinking; ability to process information in a complex way; observation; ability to admire new ideas; ability to hypothesize; speed in learning; wide vocabulary; curiosity, etc. In addition to these features, intellectually gifted children and young people have a number of specific traits, including perfectionism and idealism; increased expectations of themselves and others; asynchrony; significant advance of peers in the level of knowledge; ability to solve problems; abstract thinking of high complexity, that sometimes causes problems with solving simple tasks, etc. ${ }^{5}$

Specific academic giftedness implies outstanding achievements in a particular academic field (mathematics, languages - native and foreign, sciences and so on). Researchers from the National Society for the Gifted and Talented (USA) refer to specific academic abilities: good memory; expanded understanding; speed in acquiring basic knowledge and skills; special interest; high learning achievements in the field of special interest; pursuit of special interest with enthusiasm and vigor $^{6}$.

\footnotetext{
${ }^{3}$ Law of Ukraine "On Basic Foundations of State Support of Gifted Children and Youth in Ukraine" (2005). Retrieved from: http://www.zakon.rada.gov.ua/

${ }^{4}$ Boichenko, M. A. (2018). Theoretical and methodological foundations of education of gifted schoolchildren in the USA, Canada and Great Britain (DSc thesis). Sumy.

5 National Society for the Gifted and Talented. Giftedness defined. Retrieved from: http://www.nsgt.org/giftedness-defined/

${ }^{6}$ Ibid.
} 
Technical giftedness is considered by most foreign scientists as a component of specific academic. However, in our study, we do not refer this type to a specific academic giftedness, as the abilities that characterize technically gifted students differ significantly from specific academic talent.

To technical we refer ability to understand issues related to technology, producing technical devices, technical invention. Technical abilities are manifested during direct work with various technical equipment or its parts, which implies presence of a special kind of mental abilities and a high level of sensory-motor skills development. It should be noted that along with a certain general ability, which can be considered as a general technical talent or technical experience acquired when working with technical devices, there are such factors as spatial and engineering thinking.

As it is rightly noted in the manual for Canadian teachers ${ }^{7}$, technically gifted students have unique characteristics that cannot always be detected by traditional identification methods. Talent in this field can be discovered through experience in engineering or software. These characteristics include: more advanced technical skills than in their peers; faster acquisition of new technical skills in the absence of special training; advanced logical thinking combined with creative thinking; having fun solving a task and having an urgent need to learn how a thing works; spending an extraordinary amount of time working with/creating the equipment; desire to experiment and make inventions; ability to extrapolate acquired knowledge and experience from one type of technical device to another; application of technical knowledge in daily practical activities; spatial thinking; well-developed fine motor skills; getting pleasure from dismantling things into separate parts and collecting them; getting pleasure from training activities that involve active participation in practical activities; practical experience; learning through construction and manipulation of objects; ability to imagine (visualize) the final product at the stage of its development.

Musical and performance giftedness. Researchers emphasize that musical giftedness is manifested earlier than all other types of giftedness - at the age of 1-2 years ${ }^{8}$. However, musical talent can also appear at a later age. The British psychologist and musician J. Sloboda notes that not always outstanding pianists recognized themselves as musically gifted in their childhood $^{9}$. The first sign of musical talent is sustained interest and

7 Teaching students who are gifted and talented: a handbook for teachers (2013). Newfoundland and Labrador Department of Education.

${ }^{8}$ Shuter-Dyson, R. (1986). Musical giftedness. In J. Freeman (Ed.), The psychology of gifted children, (pp. 159-183). Chichester: Wiley.

${ }^{9}$ Sloboda, J. (1985). The musical mind: the cognitive psychology of music. Oxford: Clarendon Press. 
enjoyment of musical sounds. In addition, such children exhibit the ability to accurately reproduce melody, which can be explained by significant musical memory - one of the most important components of musical talent ${ }^{10}$.

Therefore, the main characteristics of a musically gifted child include increased interest in music and music playing at an early age; ability to recognize subtle differences and easily reproduce samples of sounds/heights/ tones/melodies/rhythms; good music memory, well-developed auditory sensations; ability to play instruments and sing; constant tapping, buzzing, singing; demonstration of emotional response to music ${ }^{11}$.

In their turn, American GT education theorists J. K. Fishell, L. Johnson, M. Chrysantou, determine a number of characteristics of performance giftedness: interest in performing arts and high motivation; flexibility of thoughts and movements; developed imagination - creates "games with characters"; ability to tell stories by bringing dramatic situations to a climax and completing them in a timely manner; ability to verbally and/or nonverbally communicate using bodily-kinesthetic means; excellent memory; ability to copy facial expressions, other people's movements, speech and intonation, convey feelings through facial expressions, gestures and movements; sense of humor; respect (empathy) for other people's feelings and experiences, recognition of the importance of everyone in the creative process; ability to take risks ${ }^{12}$.

According to G. Davis and S. Rimm, the main characteristics of artistic giftedness are: interest in fine arts at an early age; ability to draw at an early age; sharp observation skills; excellent visual memory; ability to solve artistic tasks independently (depth, perception, light, etc.); huge concentration in drawing; ability to portray complex mental images, such as three-dimensional configurations; active imagination; ability to navigate the environment morally and physically; ability to manage spatial ${ }^{13}$.

Creativity as a type of giftedness in the broad sense characterizes ability of a person to produce unusually useful ideas. According to R. Franken, creativity is an ability to generate or recognize ideas, alternatives, or opportunities that may be useful for solving problems, communicating with others, entertaining oneself and others ${ }^{14}$. In this definition, solving problems

\footnotetext{
${ }^{10}$ Winner, E. (2000). The origins and ends of giftedness. American Psychology, 55, 159-169.

11 Musical giftedness. Retrieved from: http://conceptionofgiftedness. weebly.com/ musical.html.

${ }^{12}$ Fishell, J. K., Johnson, L., Chrysantou, M. (2003). Identifying and nurturing abilities in the dramatic arts. In P. Olszewski-Kubilius, L. Limberg-Weber, S. Pfieffer (Eds.), Early gifts: Recognizing and nurturing children's talents. Waco TX: Prufrock Press Inc.

${ }_{13}$ Davis, G. A., Rimm, S. A. (2004). Education of the gifted and talented. Boston, MA: Allyn \& Bacon.

${ }^{14}$ Franken, R. E. (1994). Human motivation. Pacific Grove, CA: Brooks/Cole.
} 
is considered alongside communication and entertainment. And if problemsolving is characteristic of exact sciences, communication and entertainment relate to creative processes in such fields as humanities, music, literature, visual arts, and the like. As an ability to produce something unique and useful creativity is considered an integral part of any kind of talent, as well as a factor contributing to transformation of talent into outstanding abilities.

Sports giftedness in foreign scientific-pedagogical discourse has a number of names: athletic giftedness, bodily-kinesthetic giftedness, psychomotor giftedness, etc. The features of sports giftedness are: better development of such qualities as agility, balance, coordination and speed compared to their peers (speed, in particular, is considered to be an inherent quality that is very difficult to "teach" and which characterizes "outstanding" athletes); ability to combine movements quickly and accurately in different types of physical activity; unprecedented interest in learning the rules of different sports and sports games and mastering necessary skills; purposefulness in mastering skills of physical activity; combination of physical skills and cognitive abilities during physical activity/sports/ participation in sports games and correct and timely use of acquired skills; interest in teaching others certain skills; outstanding achievements in one or more sports; getting pleasure from physical activity classes; good motor memory; good coordination of movements; outstanding leadership skills in sports / physical activity (athletically gifted students are actively involved in the physical activity of others and are proud not only of their achievements, but also help classmates and team members to play / perform certain activities better) ${ }^{15}$.

Leadership is an ability to influence activities of individuals or groups to achieve a specific goal. OIt is undeniable that early identification of leadership qualities, like any other manifestation of giftedness, is extremely important for the full and effective disclosure of the gifted child's potential.

\section{Forms of pedagogical support of gifted children and youth in the out-of-school environments of the USA and Canada}

In the specified countries there is a wide offer of services for gifted children and youth provided in the framework of out-of-school education institutions.

In the USA and Canada, the main providers of pedagogical support for gifted and talented are research institutes/centers involved in studying giftedness, which offer a wide range of extracurricular activities and

15 Teaching students who are gifted and talented: a handbook for teachers (2013). Newfoundland and Labrador Department of Education. 
programs for children and youth with different types of giftedness (intellectual, specific academic, artistic, musical and performance, etc.).

A bright example of such a provider is Institute for Educational Advancement (IEA) (USA) ${ }^{16}$, which offers support for gifted children and youth (2-18-year-old) with high abilities in different spheres. Each IEA program is designed to serve the complex intellectual, social, emotional, spiritual, and physical needs of the specified category.

The offer of IEA gifted services covers:

- advanced supplemental enrichment classes;

- summer program "Explore";

- summer camps for gifted youth;

- workshops on different topics ${ }^{17}$.

Enrichment classes for gifted children and youth (from preschoolers to high school students) are oriented towards deepening their knowledge in STEM, arts, and humanities and are often taught on the interdisciplinary basis. Students can choose after-school, weekend, or summer enrichment classes. In the framework of the summer program "Explore" high school students get hands-on, real-world experience under supervision of professional mentors-researchers. IEA also offers residential summer camps for gifted children and youth (10-15 years old) which are aimed at disclosing potential of this category of students together with their social and emotional development.

We'd like to emphasize that summer programs are a widespread and popular form of pedagogical support for gifted children and youth in the United States and Canada. These programs are designed to provide pedagogical support for gifted students in such fields as social and natural sciences, humanities, arts, etc. through creating favorable environment for developing their abilities and talents.

As a rule, summer programs for high school students in the USA and Canada are provided by governor schools, local districts, colleges and universities, both on campus and in specially organized places where classes with gifted students are held by teachers of higher education institutions.

It should be noted that summer programs for gifted and talented children and youth include both summer camp (or campus) accommodation and summer hometown visits. Most summer programs are designed in the format

16 Institute for Educational Advancement. Programs. Retrieved from: https://educationaladvancement.org/programs/.

${ }^{17}$ Ibid. 
of courses, but some of them require experimental research and internships. Camp-based programs are generally restricted to the middle school age ${ }^{18}$.

In this context deserves attention University of Iowa, which offers a wide variety of summer programs for gifted children and youth of school age. Each summer, more than 450 gifted secondary and high school students attend one of eight summer camps located on campus, and more than 500 gifted elementary school students attend classes at one of eight specialty centers in Iowa, Illinois and Florida - under special program Challenges for Elementary Students (CHESS).

Gifted secondary and high school students from 25 states spend one, two or more weeks researching, inventing, learning to solve problems, and working on a computer. They study mathematics, anthropology, medicine, literature, law, etc. In addition to advanced study of these subjects, students are engaged in pottery, visit theatrical performances, relax at Lake Macbride state park or learn to dance.

Summer camp organizers note that living in one of America's leading research universities allows students not only to feel like real students, but also to use the university facilities, as well as to familiarize themselves with its peculiarities, which can be a crucial factor when choosing future place of study.

Participation in summer programs is mostly paid, but gifted and talented students can receive a scholarship. As a rule, scholarship programs envisage involvement of students in volunteering for the benefit of individuals or community. For example, under the Iowa Talent Project, students care for animals at the Iowa City Animal Shelter; Environmental Health Sciences Institute for Rural Youth program provides for cleaning territories; students participating in the Iowa Governor's Institute for Gifted and Talented program collect garbage at Iowa City Park; Project Achieve participants share experience with members of United Action for Youth; and gifted students who participate in the Iowa Summer Institute for the Arts and Sciences program visit residents at the Iowa City's Lantern Park Care Facility. According to the program organizers, such activities are of benefit to all participants ${ }^{19}$.

One more example of a summer camp for gifted children and youth is Burgundy Center for Wildlife Studies, which offers three types of programs:

${ }^{18}$ Summer Enrichment Programs - Types of Programs, Summer Programs: An Example, Program Success: Some Evaluative Data, Conclusion - Students, Talented, Gifted, and Individuals. StateUniversity.com. Retrieved from: http://education.stateuniversity.com/pages/ 2468/Summer-Enrichment-Programs.html\#ixzz3y67Fz1Zj

${ }^{19}$ Freeman, J. (2002). Out-of-school educational provision for the gifted and talented around the world: A report for the Department of Education and Skills. London. 
junior program (8-10 years old); senior program (11-15 years old) and adult program (21+). The first two programs are oriented towards intellectual, emotional, and physical development of gifted children and youth in the process of taking care of the natural world. According to the information, given on the website of the camp, it "incorporates creativity, humor, games, hikes, arts and music into a relaxed but high quality program focusing on animals, plants, geology, astronomy, ecology and conservation" 20 .

It is worth noting that Burgundy Center for Wildlife Studies is situated in Cooper's Cove Wildlife Sanctuary - an open valley that extends into classic West Virginia hills and hollows and comprises 506 acres of forest and meadows that are characterized by a great diversity of plant and animal life (owls, thrushes, warblers, deer, foxes, flying squirrels). There are also plenty of unusual ferns and mushrooms which can be studied by campers ${ }^{21}$.

The opportunities to disclose potential of artistically gifted children and youth and develop their skills in visual \& performing arts, cooking, etc. as well as communicate with peers with similar interests as part of caring camp community are available at Maine Arts Camp ${ }^{22}$.

At Maine Arts Camp Gifted children and youth are offered a number of activities:

- visual arts;

- theatre;

- culinary arts;

- athletic activities;

- dance;

- videography/photography;

- music;

- writing $^{23}$

In the framework of visual arts gifted campers can improve their skills in acrylic painting, bead weaving, embroidery, cartooning, enameling, fabric design, fused glass jewelry, metal jewelry, mosaics, needle felting, pen \& ink, portraiture, stained glass, clay sculpture, etc. Choosing theatre gifted children and youth can try themselves in acting, directing, improvisation, and musical theater. The culinary arts program offers interesting cooking classes, e.g. Death by Chocolate, La Italiana Cucina, Fusion Cuisine, Cooking 101, Baking, etc., attending which campers learn to cook exquisite

${ }^{20}$ Burgundy Center for Wildlife Studies. Retrieved from: http://www.burgundycenter.org/ about-us/facilities/.

${ }^{21}$ Ibid.

${ }^{22}$ Maine Arts Camp. Retrieved from: https://maineartscamp.com/.

${ }^{23}$ Ibid. 
dishes, such as chocolate chipotle truffles, chicken curry, apple noodle kugel, cinnamon monkey bread, sfingi or zeppole, japanese salad with ramen, cajun blackened shrimp tacos and so on. Gifted children and youth can also engage in sports (soccer, archery, or indoor tennis, kayaking, hiking, road biking, yoga, ultimate frisbee, fitness) and dance (choreography, ballet, hip hop, jazz, modern/contemporary, cardio dance). Maine Arts Camp provides opportunities to master photography and videography, explore the concepts of composition, exposure, depth of field, perspective, etc. while attending classes in narrative film, special effects, digital photography, advanced digital photography, documentary film, pinhole camera, alternative processes. It is worth noting that music programs at this camp are designed for both experienced musicians and campers-amateurs and include such activities as rock shop, chorus, guitar, songwriting, ukulele and other rotating music activities. For linguistically gifted children and youth there is a program focusing on storytelling skills development, which includes such activities as creative writing, tabletop roleplaying, fiction writing, script writing, songwriting ${ }^{24}$.

Thus, participation in summer programs gives gifted students the opportunity to show academic abilities, personal qualities and unique traits; get a new interesting experience; meet friends who have the same interests; get an incentive to learn and put knowledge into practice; learn to be independent.

\section{Forms of pedagogical support of gifted children and youth in Ukrainian out-of-school education institutions}

In Ukraine there is a large network of out-of-school education institutions that provide pedagogical support for gifted children and youth.

According to the Law of Ukraine "On out-of-school education" ${ }^{25}$, outof-school education is a set of knowledge, skills and abilities acquired by pupils, students and listeners in out-of-school education institution, other subjects of educational activity that provide out-of-school educational programs. Consequently, an out-of-school education institution is a component of the out-of-school education system that provides knowledge, forms skills and interests, supports person's needs in creative self-realization and intellectual, spiritual and physical development, prepares for active professional and social activities, creates conditions for social protection and

\footnotetext{
${ }^{24}$ Maine Arts Camp. Retrieved from: https://maineartscamp.com/.

25 Law of Ukraine "On out-of-school education" (2000). Retrieved from: https://zakon.rada.gov.ua/laws/show/1841-14.
} 
organization of meaningful leisure in accordance with abilities, gifts and health status of pupils, students and listeners ${ }^{26}$.

The structure of out-of-school education includes:

- out-of-school education institutions;

- other education institutions, in particular: centers of out-of-school education, general secondary education institutions regardless of subordination, types and forms of ownership, including schools of social rehabilitation, inter-school educational-industrial complexes, institutions of vocational training;

- circles, sections, clubs, cultural-educational, sports-recreational, scientific-research associations on the basis of general secondary education institutions, inter-school educational-industrial complexes, institutions of vocational training;

- clubs and associations at the place of residence irrespective of subordination, types and forms of ownership;

- cultural-educational, fitness-recreational, sports and other educational establishments, institutions;

- foundations, associations whose activities are related to the out-ofschool education functioning ${ }^{27}$.

It should be emphasized that all the above mentioned out-of-school education institutions provide pedagogical support for children and youth with different types of giftedness. An example of such a provider of educational services and pedagogical support in Ukraine is Municipal Institution of Sumy Regional Council - Regional Center for Out-of-school Education and Work with Talented Youth. It is a comprehensive, multidisciplinary out-of-school education institution; organizational, coordination, methodological and information center, which works with children and student youth in Sumy region ${ }^{28}$.

It offers broad opportunities for disclosing potential of gifted children and youth in such areas as:

- humanities and recreational;

- artistic and aesthetic;

- social and rehabilitation;

- tourist and local lore;

26 Law of Ukraine "On out-of-school education" (2000). Retrieved from: https://zakon.rada.gov.ua/laws/show/1841-14.

${ }^{27}$ Ibid.

${ }^{28}$ Municipal Institution of Sumy Regional Council - Regional Center for Out-of-school Education and Work with Talented Youth. Retrieved from: http://ocpo.sumy.ua/golovna/prozaklad.html. 
- physical culture and sports;

- ecological-naturalistic;

- scientific and technical;

- research-experimental;

- AIY (Active Intelligent Young) ${ }^{29}$.

An important role in pedagogical support of gifted children and youth plays Minor Academy of Sciences of Ukraine (MAS). Annually, MAS conducts about 30 national events of scientific and methodological orientation and more than 40 mass events for gifted children and youth. The listeners of MAS also participate in various international events, for example "Destination Imagination" - one of the world's largest creative educational programs, launched in the United States. The program is aimed at preparing students for professional challenges of the 21st century, educating future generation of innovators and leaders. It covers more than 30 countries on 6 continents, more than 150,000 participants annually ${ }^{30}$.

Research work in MAS is organized in the framework of scientific departments and sections. According to the data provided on MAS website, its listeners prefer conducting research in the fields of philology and the arts $(25 \%)$, chemistry and biology, ecology and agrarian sciences (23\%), history and geography $(20 \%)$. Fewer listeners study in the sections of scientific departments of mathematics (10\%), computer science $(7 \%)$, physics and astronomy (6\%), technical sciences (4\%). As a rule, MAS listeners participate in various regional, national, international intellectual contests, tournaments, competitions and show a high level of preparation and creativity. A significant event in MAS is annual All-Ukrainian competitiondefense of research works by students-members of MAS. About 100,000 high school students from all over Ukraine take part in all stages of the competition-defense, from which more than 1000 participate in the final stage.

Thus, Ukrainian out-of-school education institutions provide such forms of pedagogical support as various hobby-classes (in arts, choreography, sports, history, STEM, etc.) and workshops, prepare gifted children and youth for participation in different contests, competitions, Olympiads and other events of regional, national and international levels.

${ }^{29}$ Municipal Institution of Sumy Regional Council - Regional Center for Out-of-school Education and Work with Talented Youth. Retrieved from: http://ocpo.sumy.ua/golovna/prozaklad.html.

${ }^{30}$ Destination Imagination Ukraine. Retrieved from: http://man.gov.ua/ua/activities/ destination_imagination. 


\section{Possibilities of implementation of positive conceptual ideas of US and Canadian experience in practice of domestic out-of-school education institutions}

Despite important achievements of domestic out-of-school education institutions in pedagogical support of gifted children and youth, there are some issues that still need improvement.

The first step in this direction can be development of legislative acts regulating provision of educational services to gifted and talented students. We consider it necessary to specify the structure of educational services for children and youth based on an adequate definition of giftedness. Unfortunately, current Ukrainian legislation on the support and protection of gifted children and youth, which consists of the Law of Ukraine "On Basic Foundations of State Support of Gifted Children and Youth in Ukraine", which in turn lists other normative documents, that regulate educational services provision to the specified category (Laws of Ukraine "On Education", "On Higher Education", "On Pre-school Education", "On General Secondary Education", "On Out-of-school Education” and other legal acts of Ukraine), contains definition that describes giftedness only as a result. Thus, according to the definition adopted at the national level in Ukraine cited above ${ }^{31}$, only a person who is a winner of competitions, contests, Olympiads and, moreover, has official written confirmation (our italics) of such victory is considered gifted. Considering a gifted person from such positions, educational policymakers do not pay attention to the child's personality with his/her abilities, natural inclinations and interests, as well as potential (our italics) to high achievements, which still need to be developed in the process of providing pedagogical support. In our opinion, the resultcentered approach to defining giftedness should be replaced by processcentered and child-centered, which will enable more children to be covered by the services. We consider it expedient to provide the definition of giftedness in the national legislative documents in a wording approximated to the relevant wording adopted by international organizations (UNESCO, OECD), the governments of the United States and Canada, in particular as a set of natural inclinations and abilities (intellectual, specific academic, technical-design, music, performing, artistic, sports, creative, leadership, etc.) that are displayed in high achievements and potential to these achievements.

In this regard, the basis for referring a person to the category of "gifted" should be a legally approved identification procedure, which in the United

${ }^{31}$ Law of Ukraine "On Basic Foundations of State Support of Gifted Children and Youth in Ukraine” (2005). Retrieved from: http://www.zakon.rada.gov.ua/. 
States and Canada includes a list of measures aimed not only at identifying intellectual and specific academic abilities (intellectual tests and analysis of assessment results), but also the use of questionnaires and tests to identify levels of creativity, motivation, divergent and critical thinking; observation; nomination (parents, teachers, classmates), analysis of product activities and student portfolio, etc.

Valuable for enhancing pedagogical support of gifted children and youth in out-of-school education institutions is US and Canadian experience of summer programs and summer camps for the gifted. In Ukraine most summer camps are aimed at recreation and entertainment while in the USA and Canada such camps offer opportunities to acquire knowledge and skills in the field of special interest. It is worth mentioning that most of Ukrainian camps, that are designed for gifted, are oriented towards development of sports talent. There are also few camps aimed at deepening gifted students' knowledge in biology, botany, zoology, ecology. The offer of American and Canadian camps for gifted is much wider: specialized camps according to types of sports; arts camps (focus on visual arts, theatre, culinary arts, dance, videography/photography, music, writing); STEM camps; robotics camp; social studies camps, etc. Special attention deserve facilities available in the American and Canadian camps, which provide gifted children and youth with all necessary equipment to conduct research or improve skills in a number of activities.

In this context we consider it expedient to implement creatively experience of organizing thematic camps for gifted children and youth by expanding the areas, in which gifted students can develop their skills and abilities, in order to involve greater number of children. In our opinion, learning and having rest in the friendly environment of peers, who share the same interests, will contribute to their intellectual, social, emotional development and creative self-realization.

\section{CONCLUSIONS}

Application of a set of methodological approaches (systems-synergetic, personality-centered, cultural and comparative) has allowed to reveal similarities and differences in pedagogical support of gifted children and youth in the out-of-school education institutions in the USA, Canada and Ukraine as an element of multifunctional, nonlinear, complex, adaptive, dynamic system of gifted education, in the framework of which the needs of every person should be met.

It has been found out that the basis for high quality pedagogical support is identification of gifted children and youth, which helps to reveal their bright individual personality traits that will enable them not only to save their identity in a rapidly changing society, but also to compete in the labor 
market. It is noted that knowing characteristics of children and youth with different types of giftedness (intellectual; specific academic (mathematical, linguistic, etc.); technical; musical and performance; artistic; sports; creativity; leadership) will facilitate the process of identification by teachers and give pedagogical support in time. It is argued that no less important is knowing manifestations of different types of giftedness for parents, who, as a rule, make decision on the choice of the out-of-school education program/service.

It is proved that participation in out-of-school education programs gives gifted children and youth the opportunity to show academic abilities, personal qualities and unique traits; get a new interesting experience; meet friends who have the same interests; get an incentive to learn and put knowledge into practice; learn to be independent.

\section{SUMMARY}

The study reveals peculiarities of pedagogical support of gifted children and youth in the out-of-school education institutions in the USA, Canada and Ukraine. On the basis of a set of methodological approaches (systemssynergetic, personality-centered, cultural and comparative) the similarities and differences in legislation of gifted education, identification of gifted children and youth, forms of pedagogical support for this category of citizens in the out-of-school education institutions in the specified countries are found out, specific forms of pedagogical support of gifted children and youth in each country are described, and positive conceptual ideas of US and Canadian experience of pedagogical support provision in the out-of-school education institutions are defined. The necessity of early identification of gifted children and youth is proved. Types of giftedness (intellectual; specific academic (mathematical, linguistic, etc.); technical; musical and performance; artistic; sports; creativity; leadership) are characterized. The relationship between proper identification of gifted individuals and the quality of pedagogical support in the out-of-school education institutions is discussed. The recommendations on creative implementation of positive US and Canadian experience in practice of Ukrainian out-of-school education institutions are given.

\section{REFERENCES}

1. Boichenko, M., Sbruieva, A. (2019). Methodological model of comparative research in gifted education in the USA, Canada and the UK. Pedagogical sciences: theory, history, innovative technologies, 4 (88), 151-163. DOI 10.24139/2312-5993/2019.04/151-163. 
2. Boichenko, M. A. (2018). Theoretical and methodological foundations of education of gifted schoolchildren in the USA, Canada and Great Britain (DSc thesis). Sumy.

3. Burgundy Center for Wildlife Studies. Retrieved from: http://www.burgundycenter.org/about-us/facilities/.

4. Davis, G. A., Rimm, S. A. (2004). Education of the gifted and talented. Boston, MA: Allyn \& Bacon.

5. Destination Imagination Ukraine. Retrieved from: http://man.gov.ua/ua/activities/destination_imagination.

6. Fishell, J. K., Johnson, L., Chrysantou, M. (2003). Identifying and nurturing abilities in the dramatic arts. In P. Olszewski-Kubilius, L. Limberg-Weber, S. Pfieffer (Eds.), Early gifts: Recognizing and nurturing children's talents. Waco TX: Prufrock Press Inc.

7. Franken, R. E. (1994). Human motivation. Pacific Grove, CA: Brooks/Cole.

8. Freeman, J. (2002). Out-of-school educational provision for the gifted and talented around the world: A report for the Department of Education and Skills. London.

9. Institute for Educational Advancement. Programs. Retrieved from: https://educationaladvancement.org/programs/.

10. Law of Ukraine "On Basic Foundations of State Support of Gifted Children and Youth in Ukraine" (2005). Retrieved from: http://www.zakon.rada.gov.ua/.

11. Law of Ukraine "On out-of-school education" (2000). Retrieved from: https://zakon.rada.gov.ua/laws/show/1841-14.

12. Maine Arts Camp. Retrieved from: https://maineartscamp.com/.

13. Masemann, V. L. (2013). Culture and education. In R. F. Arnove, C. A. Torres, F. Stephen (Eds.), Comparative education: the dialectic of the global and the local, (pp. 113-131). Lanham: Rowman \& Littlefield.

14. Municipal Institution of Sumy Regional Council - Regional Center for Out-of-school Education and Work with Talented Youth. Retrieved from: http://ocpo.sumy.ua/golovna/pro-zaklad.html.

15. Musical giftedness. Retrieved from: http://conceptionofgiftedness. weebly.com/musical.html.

16. National Society for the Gifted and Talented. Giftedness defined. Retrieved from: http://www.nsgt.org/giftedness-defined/.

17. Shuter-Dyson, R. (1986). Musical giftedness. In J. Freeman (Ed.), The psychology of gifted children, (pp. 159-183). Chichester: Wiley.

18. Sloboda, J. (1985). The musical mind: the cognitive psychology of music. Oxford: Clarendon Press.

19. Summer Enrichment Programs - Types of Programs, Summer Programs: An Example, Program Success: Some Evaluative Data, 
Conclusion - Students, Talented, Gifted, and Individuals. StateUniversity.com. Retrieved from: http://education.stateuniversity.com/ pages/2468/Summer-Enrichment-Programs.html\#ixzz3y67Fz1Zj.

20.Teaching students who are gifted and talented: a handbook for teachers (2013). Newfoundland and Labrador Department of Education.

21. Winner, E. (2000). The origins and ends of giftedness. American Psychology, 55, 159-169.

\section{Information about the author:} Maryna Boichenko,

Doctor of Pedagogical Sciences, Associate Professor, Associate Professor of the Chair of Pedagogy,

Sumy State Pedagogical University named after A. S. Makarenko

87, Romenska str., 40002, Sumy, Ukraine ORCID ID: orcid.org/0000-0002-0543-8832 